\title{
Teledentistry and the Unified Health System: An Important Tool for the Resumption of Primary Health Care in the Context of the COVID-19 Pandemic
}

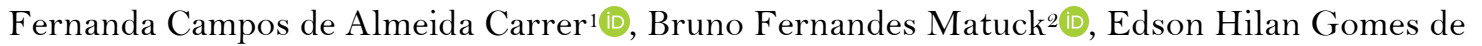

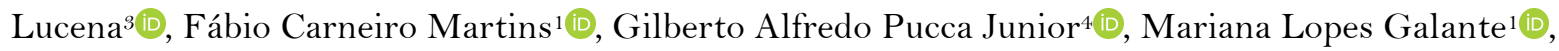 \\ Maria Fernanda de Montezuma Tricoli ${ }^{5}$ (D), Mary Caroline Skelton Macedo 6 (1)
}

\footnotetext{
${ }^{1}$ Department of Social Dentistry, Faculty of Dentistry, University of São Paulo, São Paulo, SP, Brazil.

${ }^{2}$ Department of Pathology, Faculty of Medicine, University of São Paulo, São Paulo, SP, Brazil.

${ }^{3}$ Department of Clinical and Social Dentistry, School of Dentistry, Federal University of Paraíba, João Pessoa, PB, Brazil.

${ }^{4}$ Department of Dentistry, University of Brasília, Brasília, DF, Brazil.

${ }^{5}$ State Health Secretariat, São Paulo, SP, Brazil.

${ }^{6}$ Department of Restorative Dentistry, Faculty of Dentistry, University of São Paulo, SP, Brazil.
}

Author to whom correspondence should be addressed: Fábio Carneiro Martins, Departamento de Odontologia Social, Faculdade de Odontologia, Universidade de São Paulo, Av. Prof. Lineu Prestes, 2227, Cidade Universitária, São Paulo, SP, Brazil. 05508-000. Phone: +551130917891. E-mail: fabio.carneiro.martins@usp.br.

Academic Editor: Yuri Wanderley Cavalcanti

Received: 19 June 2020 / Accepted: 06 July 2020 / Published: 06 August 2020

How to cite this article: Carrer FCA, Matuck BF, Lucena EHG, Martins FC, Pucca Junior GA, Galante ML, et al. Teledentistry and the Unified Health System: an important tool for the resumption of primary health care in the context of the COVID-19 pandemic. Pesqui Bras Odontopediatria Clín Integr. 2020; 20(supp1):e0140. https://doi.org/10.1590/pboci.2020.155

\begin{abstract}
This paper describes the possibilities of using Teledentistry to expand and qualify health care in oral health care networks. WHO already recommended to its member countries, even before the pandemic, Telehealth as a strategy to improve the quality of services, especially in universal systems, as the Unified Health System (SUS). Teledentistry opens opportunities for oral health to resume the provision of various services, remotely, such as: 1) Tracking, active search, monitoring of priority users, those at risk and with systemic problems, suspicions of COVID-19 and contacts, through Telemonitation; 2) Initial listening, individual or collective educational activities, through Teleorientation; 3) Discussion of clinical cases for the definition of the opportunity / need for operative procedures, matrix support, sharing, solution of doubts among professionals and between these and teaching and research institutions, by Teleconsulting, among others. In addition to a review of Teledentistry in the context of the pandemic, we conceptualized the terms used and possibilities offered to SUS professionals, in addition to specifying the possible protocols for recording these activities to provide safe data for their monitoring and evaluation. Besides, we bring a brief discussion with promising experiences, carried out in the pre- and trans-pandemic contexts, which can be important strategies for the resumption of oral health in the post-pandemic scenario.
\end{abstract}

Keywords: Telemedicine; Community Dentistry; Public Policy; Coronavirus Infections. 


\section{Introduction}

On March 1 1, 2020, the World Health Organization (WHO) declared a pandemic state of COVID-19, a new lung infection, which started in the city of Wuhan (China) and caused symptoms of the severe acute respiratory syndrome [1]. The biological agent that causes this affection is a coronavirus, a virus known for two other epidemics of the 21st century: SARS (2002) and MERS (2011), which had their dissemination restricted to Southeast Asia.

COVID-19 differs from these other epidemics in its high and rapid spread around the world; such effectiveness is based on three pillars: 1) Long incubation period; 2) Relative lethality, and 3) High transmissibility of asymptomatic individuals [2].

COVID-19 has a special impact on dentistry, as studies indicate sites in the oral cavity as possible foci of entry of the coronavirus in human host cells. Studies carried out with other coronaviruses in animals demonstrate that angiotensin receptors present in the ducts of the salivary glands, may be the primary target of cellular invasion of the pathogen [3].

The fact that this virus is present within cells of oral tissues mitigates the chance that preoperative mouthwashes eliminate the coronavirus from salivary and crevicular secretions [4]. This causes the aerosol generated during dental procedures to be potentially contaminated.

Therefore, dental activity is one of the most critical, since most of the surgical procedures generate aerosols, in addition to this, there are problems like the scarcity of personal protective equipment, the lack of clear biosafety protocols and the need to preserve health teams and to reduce the risk of contamination of the services users. In view of this scenario, health systems have suspended elective procedures in dentistry, with maintenance only of urgencies and emergencies, in several countries, as recommended by various institutions and local governments [5-9].

In this context, Teledentistry has been cited by scientific articles [10-12] and government documents, as an alternative to guarantee health care to the population. In addition, in the context of the Unified Health System (SUS), Oral Health Teams (ESB) can make use of this type of tool to carry out activities that integrate them to the multi-professional health team in facing the pandemic, such as tracking, Teleorientation and Telemonitoring suspected cases of COVID-19 and their contacts. The purpose of this critic review is to describe and analyze, based on the best available scientific evidence, the possibilities of action and implementation of Teledentistry, as a strategic tool for the oral health care provision in the context of the pandemic of COVID-19, observing the Brazilian norms, the guidelines of the Unified Health System and the possibilities for the permanence of this technology-mediated care in the post-pandemic scenario.

\section{Teledentistry: A Brief Review of the Literature}

Teledentistry has been shown to be effective in cost and dissemination of access, being a means of democratization and equity, with advantages related to increased resolution and reduction of waiting time and treatment costs [13-15]. A systematic review showed its cost-benefit ratio with patients living in rural areas, proving to be monetarily effective with the implementation of Teledentistry in dental practices. This study also showed that Teledentistry can be efficient in screening for oral lesions, especially in school programs, in rural areas, and with limited access to long-term care and facilities [16]. 
The use of Information and Communication Technologies (ICT) occurs as part of public dental health services in Latin American countries, such as Brazil, Colombia and Uruguay, to improve continuing education and collaborative research between national and foreign institutions [15,17]. In Brazil, through ICT, information was exchanged between universities and primary care professionals, adding values to the teachingservice relationship and being an innovative form of service and quality of service [18]. These technologies, which are also useful for training guidance and continuing education activities, in this pandemic moment, have been used for pre-screening, guidance of professionals and patients, in countries such as Paraguay and Costa Rica [19,20].

However, there is a shortage of Teledentistry projects in developing countries, which has been attributed to the conservatism of decision-makers, the lack of resources, infrastructure, and ICT equipment [21]. Another problem is the provision of dental care services still based on emergency and curative care, with a lack of preventive care protagonism [21]. With the COVID-19 crisis, the need to incorporate Teledentistry into the routine of dental care emerged, especially in the Unified Health System [22].

The pandemic introduced extra concerns to professionals and users of oral health services, including patients diagnosed with head and neck cancer, considering that: 1) Some patients are not emotionally or psychologically prepared to receive life-changing treatments; 2) Patients diagnosed with cancer or suspected malignant lesions should be monitored constantly and; 3) Lack of dental care can lead to an increase in undiagnosed cases, causing future damage to the patient due to delayed diagnosis [23].

The use of ICT to provide dental care remotely can allow Oral Health Teams to screen for emergency and urgent dental care, avoiding unnecessary dislocation of users to health facilities. On the other hand, those who do not offer this type of service must continue to fulfill their continuing professional obligation to answer questions and not abandon patients [24].

A rapid review with recommendations for the re-opening of dental services found that $94 \%$ of sources provide information on how to group patients, mainly by phone, to include risk assessment of potential COVID-19 status (for example, positive COVID-19, suspected of COVID-19, asymptomatic special need / protection), which can contribute to the tracking and telemonitoring of sick users (symptomatic or asymptomatic) and their contacts. Some studies recommend strategies such as temperature screening at reception, telephone and video consultations, telephone screening of all patients for signs or symptoms of respiratory disease and systematic patient assessment at check-in at dental clinics [25].

\section{Fundamental Terms Related to Teledentistry: Definitions, Possibilities of Operation and Registration in Primary Health Care}

The data will be presented in Table 1, which describes the fundamental terms in Teledentistry the possibilities of action and registration in PHC work process, in the context of SUS, in accordance with Federal Dentistry Council resolutions (Resolution CFO-226/2020 and Resolution CFO-228/2020) [26,27] and Ordinance No. 526, of June 24, 2020 from the Ministry of Health [28]. 
Table 1. Fundamental terms in Teledentistry, possibilities of action and registration in Primary Health Care (PHC).

Term

Telehealth

Provision of services associated with health care, in cases where distance is a critical factor. Such services can be provided through the use of communication technologies, with the objectives of continuing education or exchange of information necessary to diagnose, treat, predict and prevent diseases [29].

Teledentistry Remote provision of dental care [30]

Telemedicine Remote provision of medical care [31].

Teleorientation Identification, through a pre-clinical questionnaire, the best time to perform the face-to-face service [26].
Possibilities at PHC

Distance learning, knowledge exchange, profescional guidance examples of solutions made possible by telehealth.

Counseling or treatment using information technology rather than direct personal contact with any patient involved [30].

Counseling or treatment using information technology rather than direct personal contact with any patient involved. It refers specifically to clinical services at a distance $[31]$. It includes preclinical care, assistance support, consultation, monitoring and diagnosis, through information and communication technology, within the scope of SUS, as well as in supplementary and private health. Understands the diagnosis and conduct via the issuance of prescriptions and medical certificates at a distance will be valid in electronic media.

Reception, screening, initial listening, and guidance, for solving doubts, clarifications and carrying out individual and collective educational activities. It can also be used to define the most opportune time to perform operative procedures.
How to Record Procedures

Compiles all or other fields, which will be described individually

Compiles all or other fields, which will be described individually

Does not apply to Dentistry.

\section{In the e-SUS dental care form}

Service location

- Others

Type of attendance

- Scheduled appointment

- Spontaneous demand:

- Initial listening / guidance

- Consultation on the day

- Urgent Care

\section{Type of consultation}

- Return consultation in dentistry, if it is

"scheduled consultation"; or

- Do not check any options, if it is

"spontaneous demand"

Oral health surveillance

- Toothache

Not identified

Procedures (quantity performed)

- Oral hygiene guidance

Other procedures (SIGTAP code)

- 03.01.01.025-0 - teleconsultation in primary care; 
Telemonitoring Remote monitoring of patient health and / or disease parameters, through ICT, which may include the collection of clinical data, transmission, processing, and management by a health professional using an electronic system [32].
Supervise the health status of users in the territories of interest, a facilitating tool for strategies for tracking families with users who have common risk factors for chronic non-communicable diseases (smokers, alcohol users, etc.). In the context of the COVID-19 pandemic, it can be used to control the isolation, quarantine and monitoring of suspected cases and their contacts; transmit data from one place to another; perform interventions at a distance (in medical terminology there is talk of respiratory, cardiac, neurological monitoring in relation to childbirth, among others) [32].
- 01.01.02.012-0 - guidance on cleaning dental prostheses;

- 03.01.06.011-8 - reception with risk classification

\section{Conduct / Outcome}

- Return for scheduled consultation; or

- High of the episode.

In the e-SUS dental care form:

Service location

- Others

\section{Type of attendance}

- Scheduled appointment

- Spontaneous demand:

- Initial listening / guidance

- Consultation on the day

- Urgent Care

Type of consultation

- Return consultation in dentistry, if it is

"scheduled consultation"; or

- Do not check any options, if it is "spontaneous demand"

Procedures (quantity performed) - Other - Oral hygiene guidance

Other procedures (SIGTAP code)

- 03.01.01.025-0 - teleconsultation in primary care;

- 01.01.02.012-0 - guidance on cleaning dental prostheses;

03.01.08.001-1 - Smoker's cognitive behavioral approach (by care / patient);

- 03.01.06.011-8 - reception with risk classification

\section{Conduct / Outcome}

- Return for scheduled consultation

- High of the episode.

*Need for adequacy: include monitoring and monitoring of users with risk factors for NCDs, Active Search; Examination for epidemiological purposes; surveillance of the health status of workers.

*It is worth mentioning that these adjustments are administrative, in the information systems, 
Teleconsultation Consultation means attendance; action to attend, diagnose or prescribe a certain medication or treatment: medical consultation [33]. Teleconsultation is the synchronous or asynchronous consultation using information and communication technology to omit the geographical and functional distance [33,34].

Teleconsulting

Consultation between workers, healthcare professionals and managers, using bidirectional professionals and managers, using bi
telecommunication instruments $[34,35]$
Diagnosis or treatment between two or more health professionals geographically separated or between health professionals and patients.
Clarification of doubts about clinical procedures, health actions and issues related to the work process [35]. Teleconsulting Telediagnostics and the Second Formative Opinion are answered by the Technical-Scientific Centers of Telessaúde Brasil Redes, based on the best and most up-to-date clinical and scientific evidence available, appropriate to the context of origin of the request, carried out by workers from Health Care in SUS, within a maximum period of 72 hours.

In municipalities where these services are not available, the tool can be used so that professionals from different levels of care can define an opportune moment for referrals, prioritizing urgent care, which is not limited to pain, and avoiding unnecessary referrals.

The Federal Council of Dentistry prohibits the use of distance dentistry, mediated by technologies, for the purposes of consultation, diagnosis, prescription and preparation of treatment plan, but admits as an exception the cases in which the patient, under the direct supervision of a Dental Surgeon, this performs exchange of information with another professional, in order to provide better patient care $[26,27]$. and do not generate financial impact.

In the e-SUS dental care record:

Service location

- Others

Type of attendance

- Scheduled appointment

- Spontaneous demand.

- Initial listening / guidance

- Consultation on the day

- Urgent Care

\section{Type of consultation}

- Return consultation in dentistry, if it is "scheduled consultation"; or

- Do not check any options, if it is "spontaneous demand"

Vigilance in oral health

- Toothache

- Not identified

\section{Other procedures (SIGTAP code)}

-03.01.01.025-0 - teleconsultation in primary care

In the municipalities where there is access to Telehealth Centers: It must be registered on the platforms made available by the centers.

In municipalities where there is no access to Telehealth Centers:

*Need for adequacy:

Tele-counseling, Tele-consultation, Teleconsultin

*It is worth mentioning that these adjustments are administrative, in the information systems, and do not generate financial impact. 


\section{Discussion}

The various specialties that perform outpatient procedures involving the head and neck region, such as dentistry, otolaryngology, and ophthalmology, suffered a "lockdown" with the installation of a new pandemic, COVID-19. This decision was based on two pillars: 1) outpatient care related to such specialties presents a high risk of contagion given the close contact of the health professional with potentially contaminated aerosols; 2) difficulty in acquiring personal protective equipment, which would make it possible to reduce operator-patient exposure [36].

To mitigate the risk of contagion and encourage social distance measures, alternatives to face-to-face service are quickly eligible. All over the world, most professions have reviewed their practices and in the health area, telehealth care is cited in the literature as an assertive and viable alternative to ensure access to the health network by patients [29].

In Brazil, where there are 26 Telehealth Centers, located in 23 of the 26 states in the country, emergency measures were taken to adapt the health services work process to the new reality imposed by the pandemic. Most councils adopted a cautious approach, which guaranteed health care mediated by information and communication technologies but restricting possible activities. In the case of the Federal Council of Medicine, although restricted to the current moment, the resolution allows teleconsultations, diagnosis, telemonitoring, tele-consultation and tele-guidance to be carried out [37].

Regarding the Federal Council of Dentistry, a regulation that made the exercise of distance dentistry, mediated by technologies, expressly forbidden for the purposes of consultation, diagnosis, prescription, and preparation of dental treatment plan was lately published. However, telemonitoring and teleorientation activities were allowed, provided they are not carried out by call centers or any other means that centralize the receipt of demands and distribute them automatically [26,27].

In addition, through this regulation, dental health plan operators and other legal entities were prohibited from advertising and using the term "Teledentistry", an international term that encompasses other expressions discussed in dentistry and that will be strategic for its resumption in the "new world", mainly in the context of Primary Health Care (PHC). This segregation of the term "Teledentistry" takes Brazil out of a world scenario, in which mediated-technology oral health care is discussed at different levels and it is up to the academy and groups that militate and study telehealth and teledentistry in Brazil resist and reaffirm Teledentistry as an area of knowledge and a health care tool.

Although the CFO resolution needs to be revised and address the needs of the trans and postpandemic world, despite all the limitations, this resolution already allows a resumption of dentistry with the tools of telemonitoring. If monitoring is surveillance, the oral health teams can perform "clinical tests, mediated by technology, for epidemiological purposes", so there is an urgent need to develop tools capable of screening for risk, active search of patients with suspected oral cancer, remote care of bedridden and patients with special needs, to "guide" family members and health service users with the use of ICT. Still, respecting the limits imposed by the Federal Dentistry Council resolution, it is possible that the oral health teams perform "initial listening", mediated by technology, to guide the user, perform pre-screening, organize the agenda and the flow in the units to avoid accumulation of patients in waiting rooms [26,36]. It is worth mentioning that managers will face problems in registering part of these procedures in the information systems since many of them are classified as "consultations".

Since the beginning of the pandemic, we have constantly observed calculations in all communication vehicles about the need for ICU beds, which contributes to the population's understanding of the seriousness of 
the problem. However, although the Ministry of Health Protocol reports that $80 \%$ of cases will be attended at PHC [38], little has been discussed about the impact on PHC, which is the level of health care where professionals work close to the territories, the families who live there and the social determinants [39]. It is in PHC that we can make people aware of their social responsibility at the moment we are living, that we can monitor suspected cases and their contacts, even with the availability of few diagnostic tests, and organize health promotion activities [40]. In addition, Technical Note No. 9/2020-CGSB / DESF / SAPS / MS states that "oral health professionals, as co-responsible for the care of the population and members of the multidisciplinary health teams, must compose the team that will carry out the actions of the FAST-TRACK COVID-19*" [36]; however, municipal managers have faced difficulties as there is no way to record the production of these professionals in the information systems, given that there have been no adjustments by the Ministry of Health in these systems.

In view of the stoppage of elective care, some reflections are necessary: "What is the meaning of dental care in the health of the user?" Can dentistry stop serving patients with chronic diseases (cardiac, diabetic, smokers and alcoholics)? How to actively search for oral cancer in the context of social isolation? How to do activities of the School Health Program without face-to-face classes?

There is no doubt that Teledentistry can be a powerful tool for safely resuming oral health care in the Unified Health System since in the context of public health, we have to plan actions based on the principles of universality, equity and wholeness.

In Rio Grande do Sul, for example, there is a very efficient service available to dentists in the Unified Health System, called "EstomatoNet", which receives a demand from dentists and primary care doctors, with questions, clinical data and even photos, to assist in the diagnosis and management of cases [41]. This same group even used the WhatsApp platform to exchange information between primary care professionals and teleconsultants in the Rio Grande do Sul telehealth networks program [42].

Still, on the Telessaúde Brasil Redes program, it is important to reinforce that there has been a great investment in the last years for the dissemination of Centers throughout the national territory and currently the Unified Health System has a qualified and capillarized network that can be used to boost teledentistry in the Unified System Health, at all levels of care, but with emphasis on primary health care, which is the level capable of implementing measures for the prevention, promotion and monitoring of risk groups.

At the Telessaúde Redes Unifesp Nucleus, questions about oral health represent $32.9 \%$ of all teleconsultants; therefore, dentistry is not negligible and deserves to be observed by the Council that regulates the practice of Dentistry, by decision-makers and formulators of public health policies, in the context of teledentistry. With regard to the "Proposed emergency support for the coordination of oral health in the State of São Paulo in the face of the COVID-19 pandemic”, it is observed that Unified Health System's workers are willing and motivated to discuss and participate in permanent education activities that respond to the qualification demands of the Oral Health Teams in the face of the COVID-19 pandemic, as the state management shows commitment to its workers and great articulation with municipal oral health coordinators and show concern about the serious situation that dentistry faces in the public service. Regarding the doubts of workers and managers, it is observed that the majority focuses on biosafety, which is natural, as Dentistry is one of the professions that most suffers from this theme in their professional practice in view of the routes transmission of the new coronavirus.

There is strong evidence in the management of chronic diseases in other areas of health in different fields, such as psychiatry and dermatology. Exams with high sensitivity and specificity demonstrate the 
effectiveness of the distance service in clinical areas and that perform outpatient procedures [43]. Within the scope of the practice of telecardiology, there is an effective relationship in resolving cases attended, of high and low complexity, with improvement in health care in regions where such care was installed. Studies show that telemedicine has an increase in treatment adherence by patients and an important reduction in the costs of tertiary care. The implementation of call centers within the scope of specialties can represent savings of up to 3546 euros for hospitals and reference centers [44]. The cost-morbidity ratio that medical specialties experience has a lower tolerance threshold than that of dental reality, even so, the practice of Teledentistry is still not as established as Telemedicine.

\section{Conclusion}

In a complex global context, characterized by the biggest contemporary health crisis imposed by the pandemic caused by the new coronavirus, added, in Brazil, with a serious political crisis, the delay in diagnosis and accumulation of needs are problems that can cause an important financial and social impact for health services and their users, and the use of Teledentistry has a great potential for coping, as it allows the reduction of geographical barriers in a country with extensive territorial dimensions, as well as the strengthening of PHC. The Unified Health System has a constitutional commitment to the universality of access, observing the equity of the actions and the integrality of care, therefore, it is up to the workers and managers of this system to provide assistance, which in the context of the pandemic can only be viable with the use of ICT. Telemonitoring and teleorientation already allow a partial resumption of PHC oral health care in the Unified Health System, but it is necessary to revise the ordinance with the inclusion of procedures such as consultation and prescription, to increase the possibilities of the work of SUS professionals. It is worth mentioning that ICT can be great allies to increase access, in this increasingly digital world, fighting this reality can mean a delay that will be charged by history.

\section{Authors' Contributions}

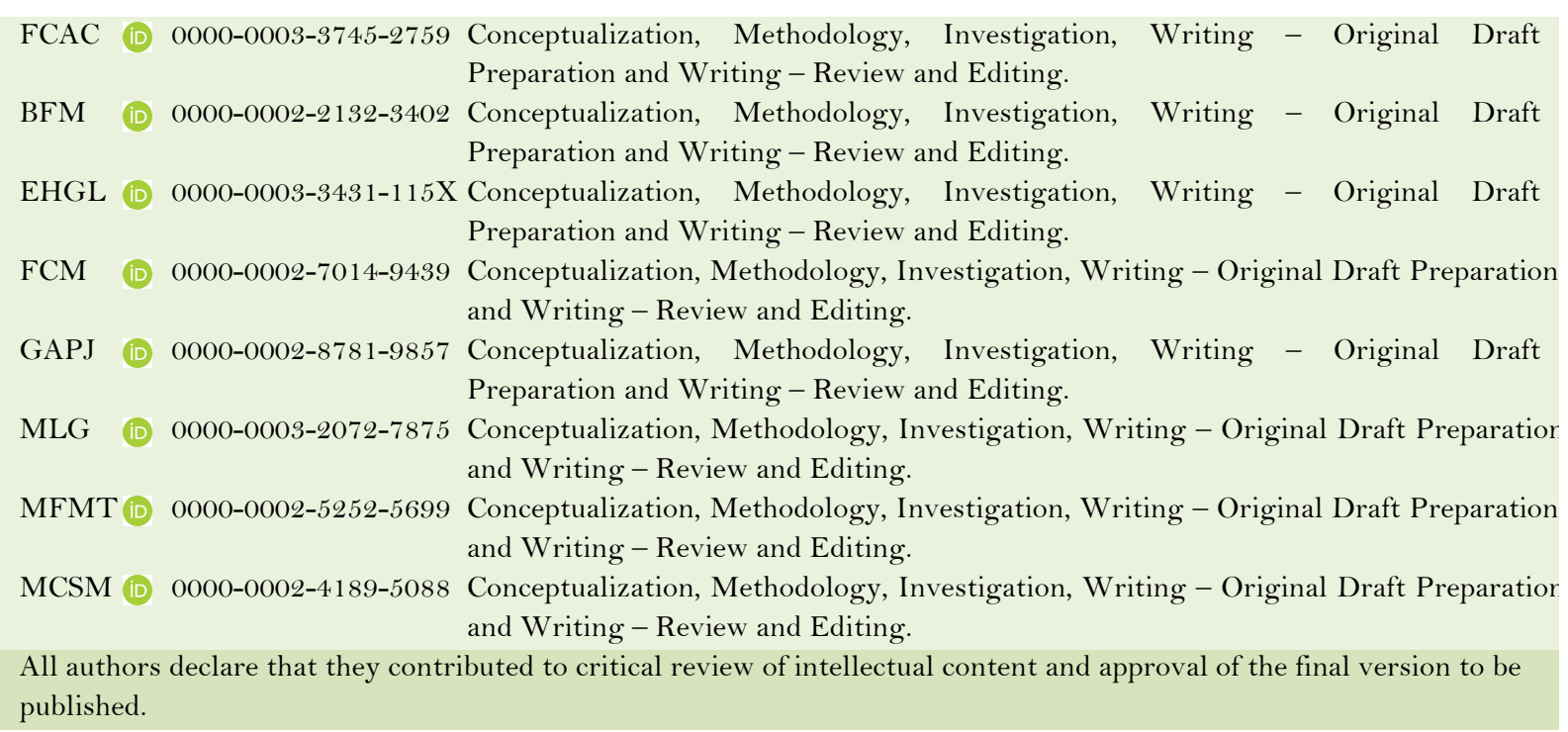

\section{Financial Support}

None. 


\title{
Conflict of Interest
}

The authors declare no conflicts of interest.

\section{Acknowledgment}

\author{
UFPB, RPN, UNIFESP, SES/SP, FOUSP, TELESSAÚDE BRASIL REDES UNIFESP.
}

\section{References}

[1] Zhu N, Zhang D, Wang W, Li X, Yang B, Song J, et al. A novel coronavirus from patients with pneumonia in China, 2019. N Engl J Med 2020; 382(8):727-33. https://doi.org/10.1056/NEJMoa2001017

[2] Lauer SA, Grantz KH, Bi Q, Jones FK, Zheng Q, meredith HR, et al. the incubation period of coronavirus disease 2019 (COVID-19) from publicly reported confirmed cases: estimation and application. Ann Intern Med 2020; 172(9):577-82. https://doi.org/10.7326/M20-0504

[3] Liu L, Wei Q, Alvarez X, Wang H, Du Y, Zhu H, et al. Epithelial cells lining salivary gland ducts are early target cells of severe acute respiratory syndrome coronavirus infection in the upper respiratory tracts of rhesus macaques. $\mathrm{J}$ Virol 2011; 85(8):4025-30. https://doi.org/10.1128/JVI.02292-10

[4] Ortega KL, Rech BO, Costa ALF, Sayans MP, Braz-Silva PH. Is 0.5\% hydrogen peroxide effective against SARSCoV-2? Oral Dis 2020. https://doi.org 10.1111/odi.13503

[5] Brasil. Ministério da Saúde. Secretaria de Atenção Primária à Saúde (SAPS). Atendimento odontológico no SUS. Brasília, DF; 2020. Available from: http://www.crosp.org.br/uploads/arquivo/ab69d79b87d04780afo8a70d8cee9d70.pdf. [Accessed on June 08, 2020]. [In Portuguese]

[6] Argentina. Ministério de la Salud. Covid-19 Atención Odontológica Programada Inicial. Available from: http://www.msal.gob.ar/images/stories/bes/graficos/0000001937cnt-covid-19-recomendaciones-atencionodontologica-programada.pdf.5. [Accessed on June 08, 2020]. [In Spanish]

[7] Chile. Minsal Orientaciones Para Atención Odontológica en Fase IV COVID-19. Available from: https://diprece.minsal.cl/wp-content/uploads/2020/03/ORIENTACIONES-ATENCION-ODONTOLOGICASCOVID-19-.pdf.6. [Accessed on June 08, 2020]. [In Spanish]

[8] American Dental Association. ADA Recommending Dentists Postpone Elective Procedures. Available from: https://www.ada.org/en/publications/ada-news/2020-archive/march/ada-recommending-dentists-postponeelective-procedures. [Accessed on June 08, 2020].

[9] Pereira LJ, Pereira CV, Murata RM, Pardi V, Pereira-Dourado SM. Biological and social aspects of coronavirus disease 2019 (COVID-19) related to oral health. Braz Oral Res 2020; 34:e041. https://doi.org/10.1590/1807-3107bor-2020.vol34.0041

[10] Kochhar AS, Bhasin R, Kochhar GK, Dadlani H. Provision of continuous dental care for oral oncology patients during \& after COVID-19 pandemic. Oral Oncol 2020; 106:104785. https://doi.org/10.1016/j.oraloncology.2020.104785

[11] Győrffy Z, Békási S, Szathmári-Mészáros N, Németh O. Possibilities of telemedicine regarding the COVID-19 pandemic in light of the international and Hungarian experiences and recommendations. Orv Hetil 2020; 161(24):983-92. https://doi.org/10.1556/650.2020.31873

[12] Giudice A, Barone S, Muraca D, Averta F, Diodati F, Antonelli A, et al. Can teledentistry improve the monitoring of patients during the Covid-19 dissemination? A descriptive pilot study. Int J Environ Res Public Health 2020; 17(10):3399. https://doi.org/10.3390/ijerph 17103399

[13] Blomstrand L, Sand LP, Gullbrandsson L, Eklund B, Kildal M, Hirsch JM. Telemedicine - a complement to traditional referrals in oral medicine. Telemed J E Health 2012; 18(7):549-53. https://doi.org/10.1089/tmj.2011.0207

[14] Estai M, Bunt SM, Kanagasingam Y, Kruger E, Tennant M. A resource reallocation model for school dental screening: taking advantage of teledentistry in low-risk areas. Int Dent $\mathrm{J}$ 2018; 68(4):262-8. https://doi.org/10.1111/idj.12379

[15] da Costa CB, Peralta FDS, Ferreira de Mello ALS. How has teledentistry been applied in public dental health services? An integrative review. Telemed J E Health 2020; 26(7):945-54. https://doi.org/10.1089/tmj.2019.0122

[16] Alabdullah JH, Daniel SJ. A systematic review on the validitidy of teledentistry. Telemed J E Health 2018; 24(8):63948. https://doi.org/10.1089/tmj.2017.0132

[17] López Jordi MD, Figueiredo MÇ, Barone D, Pereira C. Study and analysis of information technology in dentistry in Latin American countries. Acta Odontol Latinoam 2016; 29(1):14-22.

[18] Tonini K, Nascimento RM, Rios MZ. Information and communication technologies for professional training in Dentistry: a telehealth / ES proposal. Rev ABENO 2018; 18:127-36.

[19] Paraguay. Ministerio de Salud Publica y Bienestar Social. Protocolo Para Atención Odontológica Durante la Pandemia de SARS-CoV-2 en la Republica Del Paraguay. Available from: 
https://www.mspbs.gov.py/dependencias/portal/adjunto/515742-

Protocolodeatencinodontolgicadurantelapandemia.pdf. [Accessed on June 08, 2020].

[20] Colegio Cirujanos Dentistas Costa Rica. Protocolo Teleconsulta Dental. Available from: http://www.colegiodentistas.org/sitCol/wp-content/uploads/2020/04/PROTOCOLO-TELECONSULTA-

DENTAL.pdf. [Accessed on June 08, 2020].

[21] Estai M, Kanagasingam Y, Tennant M, Bunt S. A systematic review of the research evidence for the benefits of teledentistry. J Telemed Telecare 2017; 24(3):147-56. https://doi.org/10.1177/1357633X16689433

[22] Villa A, Sankar V, Shiboski C. Tele (oral) medicine: a new approach during the COVID-19 crisis. Oral Dis 2020; 10.1111/odi.13364. https://doi.org/10.1111/odi.13364

[23] Kanatas A, Rogers SN. The After Diagnosis Head and Neck cancer - specific Patient Concerns Inventory ( HaNC $\mathrm{AD}$ ) as a pre - treatment preparation aid during the COVID - 19 pandemic. Eur Arch Otorhinolaryngol 2020; 277(7):2 141-5. https://doi.org/10.1007/s00405-020-05995-9

[24] Royal College of Dental Surgeons of Ontario. COVID-19: Guidance for the Use of Teledentistry. Available from: https://www.rcdso.org/en-ca/rcdso-members/2019-novel-coronavirus/covid-19---emergency-screening-of-dentalpatients-using-teledentistry. [Accessed on June 08, 2020].

[25] Cochrane Oral Health. Recommendations for the re-opening of dental services: a rapid review of international sources. Available from: https://oralhealth.cochrane.org/news/recommendations-re-opening-dental-services-rapidreview-international-sources. [Accessed on June 08, 2020].

[26] Conselho Federal de Odontologia. Resolução CFO-226 de 04 de Junho de 2020. Dispõe sobre o exercício da Odontologia a distância, mediado por tecnologias, e dá outras providências. Available from: http://www.crosp.org.br/uploads/arquivo/e1eb52fada70ddc938113152ba2b9cea.pdf. [Accessed on June 04, 2020] [In Portuguese]

[27] Conselho Federal de Odontologia. Resolução CFO-228/2020. Regulamenta o artigo $5^{\circ}$ da Resolução CFO 226/2020. Available from: http://www.crosp.org.br/uploads/arquivo/9fb935fo4d 1b8e4d8eed246b9e82aaof.pdf. [Accessed on August 01, 2020] [In Portuguese]

[28] Brasil. Ministério da Saúde. Secretaria de Atenção Especializada à Saúde. Portaria No 526, de 24 de junho de 2020. Inclui, altera e exclui procedimentos da Tabela de Procedimentos, Medicamentos, Órteses, Próteses e Materiais Especiais do SUS. Available from: https://www.in.gov.br/web/dou/-/portaria-n-526-de-24-de-junho-de-2020264666631. [Accessed on August 01, 2020] [In Portuguese]

[29] World Health Organization. Global diffusion of eHealth: making universal health coverage achievable. Report of the third global survey on eHealth. Geneva: WHO; 2016. Available from: https://apps.who.int/iris/bitstream/handle/10665/252529/9789241511780-eng.pdf?sequence =1. [Accessed on June 08, 2020].

[30] Khan SA, Omar H. Teledentistry in practice: literature review. Telemed J E Health 2013; 19(7):565-7. https://doi.org/10.1089/tmj.2012.0200

[31] Lopes MACQ, Oliveira GMM, Ribeiro ALP, Pinto FJ, Rey HCV, Zimermanet LI, et al. Diretriz da Sociedade Brasileira de Cardiologia sobre Telemedicina na Cardiologia - 2019. Arq Bras Cardiol 2019; 113(5):1006-56. https://doi.org/10.5935/abc.20190205 [In Portuguese]

[32] Ferrer J, Nicuesa M, Esteban D, Ayala R. Conceitos. Monitoramento. Available from: https://conceitos.com/monitoramento/. [Accessed on June 04, 2020]. [In Portuguese]

[33] Dicio. Dicionário Online de Português. Porto: 7Graus, 2020. Available from: https://www.dicio.com.br/consulta/. [Accessed on June 05, 2020]. [In Portuguese]

[34] Deldar K, Bahaadinbeigy K, Tara SM. Teleconsultation and clinical decision making: a systematic review. Acta Inform Med 2016; 24(4):286-92. https://doi.org/10.5455/aim.2016.24.286-292

[35] Brasil. Ministério da Saúde. Portaria No 2.546, de 27 de Outubro de 2011 . Redefine e amplia o Programa Telessaúde Brasil, que passa a ser denominado Programa Nacional Telessaúde Brasil Redes (Telessaúde Brasil Redes). Available from: https://bvsms.saude.gov.br/bvs/saudelegis/gm/2011/prt2546_27_10_2011.html. [Accessed on June 05, 2020]. [In Portuguese]

[36] Brasil. Ministério da Saúde. Secretaria de Atenção Primária à Saúde (SAPS). Nota Técnica No 9/2020CGSB/DESF/SAPS/MS. COVID-19 e Atendimento Odontológico no SUS. Março de 2020. Available from: http://website.cfo.org.br/wp-content/uploads/2020/03/COVID-19_ATENDIMENTO-ODONTOLOGICO-NOSUS.pdf. [Accessed on June 05, 2020]. [In Portuguese]

[37] Conselho Federal de Medicina. Ofício $\mathrm{CFMN}^{\circ} 1756 / 2020-\mathrm{COJUR}$. Informa sua decisão de reconhecer a possibilidade e a eticidade de uso da telemedicina no País. 19 de março de 2020. Available from: http://portal.cfm.org.br/images/PDF/2020_oficio_telemedicina.pdf. [Accessed on June 05, 2020]. [In Portuguese]

[38] Brasil. Ministério da Saúde. Secretaria de Atenção Primária à Saúde (SAPS). Protocolo de Manejo Clínico do Coronavírus (COVID-19) Atenção Pa Primária. Available https://portalarquivos.saude.gov.br/images/pdf/2020/April/08/20200408-ProtocoloManejo-vero7.pdf. [Accessed on June 05, 2020]. [In Portuguese] 
[39] Vitória AM, Campos GWS. Só com APS forte o sistema pode ser capaz de achatar a curva de crescimento da pandemia e garantir suficiência de leitos UTI. Available from: http://www.cosemssp.org.br/wpcontent/uploads/2020/04/So-APS-forte-para-ter-leitos-UTI-.pdf. [Accessed on June 03, 2020]. [In Portuguese]

[40] Starfield B. Primary Care: Balancing Health Needs, Services, and Technology. New York: Oxford University Press; 1998. 448p.

[41] Carrard VC, Roxo Gonçalves M, Rodriguez Strey J, Pilz C, Martins M, Martins MD, et al. Telediagnosis of oral lesions in primary care: the EstomatoNet Program. Oral Dis 2018; 24(6):1012-9. https://doi.org/10.1111/odi.12851

[42] Carrard VC, Martins MA, Molina-Bastos CG, Gonçalves MR. WhatsApp: a telemedicine platform for facilitating remote oral medicine consultation and improving clinical examinations - some considerations. Oral Surg Oral Med Oral Pathol Oral Radiol 2017; 123(3):408. https://doi.org/10.1016/j.oooo.2016.09.228

[43] Hersh W, Helfand M, Wallace J, Kraemer D, Patterson P, Shapiro S, et al. A systematic review of the efficacy of telemedicine for making diagnostic and management decisions. J Telemed Telecare 2002; 8(4):197-209. https://doi.org/10.1258/135763302320272167

[44] Comín-Colet J, Enjuanes C, Verdú-Rotellar JM, Linas A, Ruiz-Rodriguez P, González-Robledo G, et al. Impact on clinical events and healthcare costs of adding telemedicine to multidisciplinary disease management programmes for heart failure: results of a randomized controlled trial. J Telemed Telecare 2016; 22(5):282-95. https://doi.org/10.1177/1357633X15600583 